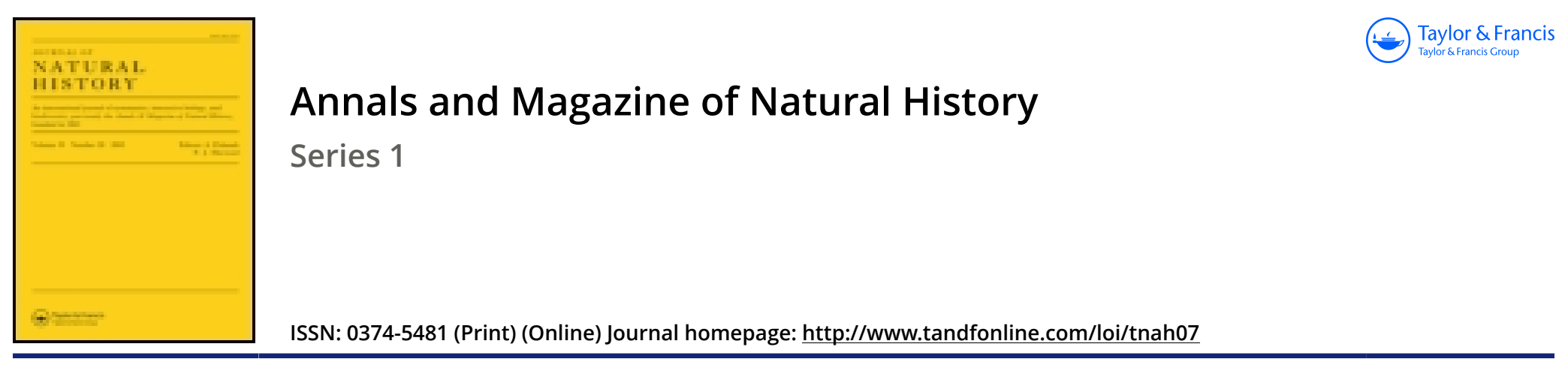

\title{
XI.-Extracts from a few rough notes of a journey across the Pampas of Buenos Ayres to Tucuman, in 1835
}

James Tweedie Esq.

To cite this article: James Tweedie Esq. (1839) XI.-Extracts from a few rough notes of a journey across the Pampas of Buenos Ayres to Tucuman, in 1835, Annals and Magazine of Natural History, 4:22, 96-105, DOI: 10.1080/00222933909512469

To link to this article: http://dx.doi.org/10.1080/00222933909512469

曲 Published online: 15 Mar 2010.

Submit your article to this journal $₫$

ai

View related articles ¿ 
claw, and the tarsus is broad with a diverging tooth. The first pair of feet is much broader than the second. The following feet terminate with a long straight claw but slightly curved in the form of a hook at the apex only, the three posterior have merely a small foliaceous appendiculated member. I did not see the branchic at their base, but very distinctly the three pairs of pseudo-abdominal feet, which consist of a securiform, lamellar basal joint, and two articulated and ciliated spines; so that there can be no doubt to which order of Crustacea this animal belongs. The cibarian apparatus seemed to me to consist of a marginated upper lip, a pair of mandibula provided with biarticulated palpi, three (?) or four (?) pairs of lamellaceous maxilla, and two sex-articulated footjaws.

\section{Plate III. Fig. 5. Chelura terebrans.}

a. The animal lying on its side, magnified four times.

$b$. The fourth and fifth caudal segment from above, as it appears when it is magnified fifteen times.

c. The same from below. The third pair of false abdominal feet is evident at the basis.

$d$. The first foot seen magnified twenty-five times.

e. One of the posterior feet with the same power.

[To be continued.]

XI.-Extracts from a few rough Notes of a Journey across the Pampas of Buenos Ayres to Tucuman, in 1835. By James Tweedie, Esq., addressed to Sir W. J. Hooker.

[Continued from p.]5.]

Thrs morning, the 26th, we regained the post-road which we had left at Pergamena, at 3 leagues beyond the post house of Cabeza del Tigere, 320 miles N.W. of Buenos Ayres. Here the tract turns more to the west, keeping along the east bank of the Rio Corcouneon, a most delightful tract to behold, being finely interspersed with woods of Algaroba and Chañeos, the river gliding on at the rate of about a mile in the hour, in a deep ravine whose sides are nearly perpendicular for 30 or 40 feet, especially the cast bank where the sun is so powerful as to dry up much of the vegetation, while on the west and north-west, where it is shaded from the midday rays, the crooked course 
of the river is tracked as far as the eye can reach by the abundance of willows that line the banks. There are, however, no beautiful slopes and rich holms here, such as grace the shores of the Clyde. We halted this day at the deserted posthouse of Lobaton, where I found the vegetation bearing a striking similarity to that which prevails around Bahia Blanca, distant more than 1100 miles.

27th. We crossed the little river called Salado de Ruiz Diaz, whose flat sides, white with a saline incrustation which crushes like frost under the foot, are denuded of vegetation for at least a hundred yards on either side the stream. At this place we had entered the province of Cordova for 20 miles, and after passing the river pursued a constantly rising road till we came to a posthouse bearing the same name as the river and situated at a considerable elevation. The land all around is very bare of herbage and dry, but gay with a species of Oxalis and the beautiful little Nierembergia gracilis. I also found the Eupatorium affine, a charming dwarf perennial. The well was the deepest I had seen on the road, 21 feet, but the water was excellent. We passed through a dry and thinly inhabited country, but looking agreeable from its natural clumps of Algarobas, \&c. The Rio Corcouñeon with its row of willow trees lay on our right, its windings marked by these trees; and our road being straight, sometimes it was close to us, at other times far distant. We saw several deserted houses and unoccupied land, though the latter was of good quality; and passed through the town of Fraile Muerto, situated close to the river, where there were some spots of fine maize, pompions, French beans and tomatos, the latter an indispensable article here.

30th. Having pursued our journey up the river and generally almost parallel to its course for nearly 100 miles, we crossed it at Esquina del Ahogada, where its name changes from Corcouñeon to Rio Terzero, it being the third river from Cordova going to Buenos Ayres. Here commenced a strange change in the face of the country, a dense forest prevailing for a vast distance, chiefly consisting of Algarobas, of which there were several beautiful varieties. The tops of these trees are often charmingly adorned with the purple flowers of a species. of mistletoe, whose blossoms are frequently more than an inch 
long; there are many species of this kind of climber, some with clusters of white and others of green flowers, all of them finely scented; and where there was a free opening to the air we observed many trees quite covered and killed with loads of different kinds of Tillandsia. The road through these ancient forests is often so circuitous that we would be going towards all the different points of the compass in the course of one day: frequently again it would become so narrow that there was scarcely room for one cart to pass along, and where its high lumbering body, swinging from side to side, was completely stopped; so that it was needful to cut away some of the branches before it could proceed. Our great line of vehicles, with the feet of the numerous cattle, raised such a tremenclous cloud of dust, that often one cart was indiscernible at the distance of another, and there was not a breath of air in these dense forests to carry off the dust.

On the afternoon of the third day after crossing the river our mules all left us on a sudden at full gallop; they had scented the water of a large lake 6 miles distant; but much as we were all in want of this necessary of life, nothing but absolute need could compel us to use it, the quality was so bad. I had gathered, when passing the Rio Terzero, several varieties of the Zirnia, an annual in English gardens; the Goodenia tuberosa, and some agreeably scented kinds of Cynanchum: little worthy of notice occurred in the dense woods, except 2 or 3 species of Cactus.

4th April. We came to the village of Los Ranchos, another poor place, containing apparently about 800 inhabitants; the houses are all constructed of unburnt bricks, the church partly of this material and partly of burnt bricks : opposite to this building is a large market square, but I saw nothing offered for sale except a cart load of beef and a few pompions. This place is considered half-way between Buenos Ayres and Tucuman. At sunset we crossed the Rio Secundo or second river from Cordova, and finding good grass stopped all night in a field of Melissa (?) sp. 6-8 feet high, here called Boldo, and in great use for dyeing, and by the addition of other substances it produces various shades of brown. This Rio Secundo was, at the time we now crossed, 200 yards 
broad, of a regular depth of 4 feet all across, and gliding slowly north-east at about a mile an hour; on our return it was quite dried up, and in place of water we found nothing but white drifting sand and gravel, brought down from the mountains of Cordova. Two more days and nights travelling broughit us to the Rio de Cordova, a fine stream of the clearest water that can be seen in any of these provinces. The bottom is stony and gravelly, the stones having been brought down from the mountains, 30 miles distant, by the current; for throughout these extensive plains not a vestige of stone or metal can be found.

6th. We rested at the passage of the river for most of the day, repairing carts, \&c. The town of Cordova is in view, 26 miles on our left, and appears charmingly situated at the foot of a ridge of hills, stretching north-west. While travelling through the woods I noticed a Passiflora, and saw several species of strong-growing Cactus; and on the steep and dry banks many of the largest Algarobas were completely killed with loads of air-plants, of which great masses hung from every branch.

8th. After passing this river, the road rises considerably, proceeding more to the north; its former direction was northwest, and is now north-north-west; the tract over which we passed was miserable, dry, and barren in the extreme; a few stunted shrubs of Chañeos, Algarobas, and some other species of Mimosa were all that could be seen. One of the latter produces a quantity of clear amber gum which distils from its beautifully green bark. At the posthouses we obtained water at from 12 to 15 feet from the surface, and in one instance the cattle were served with it at the rate of a Spanish dollar for 100 beasts, the water being raised by a horse in a sheep's hide from a well 5 yards deep. In this dry tract we passed over I8 miles, which having been set on fire accidentally by a camp, had been left a naked plain of black ashes, with the bare stems of the shrubs remaining erect like blackened rods. These extensive conflagrations are common in these districts, making a splendid appearance by night. With the first shower that falls on the scorched ground a lovely crop springs up, consisting of Oxalis, red, yellow, and rose-coloured, mingled 
with different kinds of Amaryllis, which spread a carpet of bloom resembling a richly stocked flower-garden.

14th. We came to the little chapel of San Juan, where, though the village consists of but 3 Ranchos, there is a pulperia or tippling dram-shop. A day was passed in repairing the carts, all of which had become loose and rickety from the long drought. No iron is used in the construction of these vehicles; even the wheels are unshod, the trams being made of hard Algaroba wood, which lasts a long time, often several years, on the stoneless roads of this country.

This place was the last post house in the province of Cordova going north-west, and here, as we were on the ridge of a mountain, we found the vegetation much more varied than of late; the Cactus tribe were especially numerous and varied; one specimen of the broad-branched kind struck me particularly, its white strong spines measuring from 6 to 9 inches in length; and the tree itself, of a conical shape (the cone reversed), with its huge body of bushy and numerous flat branches, could not be of less weight than 10 to 12 tons. There are also several Mimosas of different species; that which is called from its hooked thorn Garro-Vato (Grip the Goat) abounds ; varying much, but always preserving a slender mode of growth and fine short pinnated leaves: unfortunately none of these were in flower. I also observed the Jormillio, a slender ever-flowering shrub, with small gummy leaves; the whole plant has a dry brown singy appearance; and a curious frutescent Solanum, whose long, oval, scarlet fruit is generally as empty as a bladder. Here also I found a beautiful shrub much resembling an apricot, its fruit; which is small and yellow, the natives assure me, when ripe, is not inferior to a good plum; but as the season was passed, I only picked up a few dry kernels, which also bore a great similarity to those of the apricot; at the lowest part of the bush was a small branch in flower: it is called here Patta.

In this neighbourhood I noticed the effects of the earthquake which had taken place while I was travelling in August of last year: pits, of various forms and depths, had opened, some only 4 feet deep, while of others we could not find the bottom; also a large deep rent or ravine, crossing our road, 
but since nearly filled up with mud: the wells, from the same cause, now only afford muddy water, and the natives are content to use what they can obtain from a pool, which occupying the centre of a field and receiving all the washing of the neighbourhood, tastes far too strong of cattle to be palateable. Yet these indolent people make no attempt to obtain a better supply of this needful element. For the same reason they neglect to cultivate the native trees, many of which, such as peaches, growing here fine and healthy by the road sides, would prove highly valuable with little trouble; but a few pompions and maize are all that they care to rear.

In the afternoon of the 15th we arrived at the Post Del Carmen, and entered the province San Jago del Esterro, lying at the north-west point of the Cordova mountains. Here the road for a short distance was of a fine hard gravel, the first I had trodden in any of the Argentine Provinces.

The Algaroba, hitherto so abundant, now gave place to several other kinds of large trees, as the Quebra Halcha, Colorada or Blanca: this names signifies the Hatchet-breaker, as the wood is so hard that a large tree of this sort is rarely felled without breaking the hatchet; the Colorada was covered with large tufts of red seed, much like the sycamore; while the Blanca is distinguished by its small myrtle-like foliage and long pendent slender boughs, which give the whole tree the appearance of a weeping willow ; its seed is a flat pap-like substance, inclosed in large flat white pods hanging in twos, threes, and fours at the tips of the slender branches like the pendulum of a clock. This tree always grows quite erect till it attains the height of 20 to 30 feet, and has a singularly majestic appearance.

We now came to a thickly wooded, but deserted country, and travelled for 50 miles without meeting with a single inhabitant, though we saw numbers of old Ranchos and the ruins of what had been good dwellings. The immense number of tigers which infest this district and destroy all the cattle, has caused the people to remove and leave to these voracious animals the exclusive possession of these extensive forests. While our beasts were feeding I took a cautious stroll into the woods and came upon what had been an Indian vil- 
lage, consisting of a few straggling huts, formed of four-forked posts, on which were laid unpruned branehes which were again covered with sods and loose earth, thus merely affording a protection from the sun, but none from the cold, these huts being entirely open at the sides. Not a human being could be seen, though it would appear that this encampment was but recently deserted, from the vegetables, pompions, tomatos, capsicums, and maize, which now covered the ground, as wild and promiscuous as if natives of the soil. In this wilderness I observed several of the small silver grey fox and a large species of hare, with a broad tail like that of the Cape sheep. Parrots and paroquets were in vast number, but no other birds. Here were some curious Cacti, of large erect growth, and 16 angles to the stem, some of the naked polelike branches being upwards of 30 feet high, beset with spines 2 to 4 inches long. The fruit is very small in proportion to the size of the species, some single plants sending out more than a hundred of these naked pole-like branches, most of which were from 6 to 8 inches through, and generally thicker at the top than bottom.

17th. At mid-day we reached the river Saladillo de Gusman, and here we were kept waiting 15 days for its decrease, the season being that of its greatest fulness, in consequence of the melting of the early fallen snow on the Cordilleras. It may seem an extraordinary circumstance, that when travelling through a country where man and beast often suffer the utmost distress for want of water, the party should at the very same time be arrested by a river whose margins were flooded for half a mile on either side beyond the ordinary channel; but such was nevertheless the case here, as in other tropical countries; the greater the heat and drought, the more swollen are the streams, which diminish in proportion as the weather becomes cold and wet. After waiting for two weeks in vain, we discovered a place, a considerable way further down, where the height of the banks had much contracted the river, and with much labour, and after cutting down many trces, our carts were dragged to the water's edge. Another Tropa, consisting of 11 similar vehicles, having joined us on the one side, while another of 13 was drawn up on the opposite bank, 
where a little village of Indian Ranchos or huts was situated close to the stream, the assemblages of drivers, passengers; and large quantities of cattle gave the place the appearance for a few days of a Highland fair. Commodities of various kinds were brought for sale, among them excellent bread, made from the flour of Algaroba pods, no way inferior to wheaten flour in taste, being sweet-flavoured, but yellow-coloured and slightly purgative at first to those who are unaccustomed to it. The husks after passing through the mill are steeped in water, which is then fermented and greedily drunk by the natives, though to strangers it is a disagreeable dirty mess. The remaining husks and sediment are afterwards dried and sold in small quantities for chewing, being somewhat sweet-tasted, though hardly so good as pea pods would be. These people thus lose nothing of their favourite Algaroba, which they gather from every tree with the greatest care, and store it up on the tops of posts, that it may be secure from the attacks of mice, \&c. On observing to a native that the Algaroba districts of Cordova and San Jago were a most barren plain, he replied it was true, but as God had given them a dry sterile soil he had blessed them with abundance of Algarobas. In exchange for beef we obtained boiled sweet batatoes and chocklos or heads of Indian corn, both boiled and roasted; also some milk of goats, for no cattle are kept here.

The task of crossing this river was truly extraordinary: the waggons being unloaded, the largest hides with which they were covered were taken off, and each, kept outstretched with branches of trees and its four corners tied together, formed a kind of oblong box, something like a rough canoe, in which were then deposited as many goods as it could hold. An old Indian woman having contracted to take over our cargo at 20 reals or $\frac{2}{3} \mathrm{ds}$ of a Spanish dollar, she alone waited upon the loading of each hide, which was done by our drivers, while the dame ordered the mode in which the several articles should be placed, paying particular attention to see that the cargo should be evenly distributed and the hide set fairly on the water. This done, a young girl was employed to swim and drag it behind her by means of a small rope fixed to one of the canoes over her right shoulder, while she held and dragged by her 
tceth. Each hide carries from 3 to 4 cwt. according to its size. The river is here about 100 yards wide. To me the task appeared a very luckless job; and when my turn came to go with my chest, boxes, and a fellow passenger, all launched into an ordinary bull's hide, with a girl, none of the strongest, to drag us, I felt considerable doubts of our safety. However nothing went wrong in crossing, either with us or a tropa of 11 carts, 28 in all, which were thus got over. The men, paid by the old woman, of whom there were 11 , were occupied in dragging our empty waggons across, in which were fixed crates of earthenware, some heavy boilers, and other articles too large for the hide boat. The passage of the waggons was a still more troublesome business; 3 men swam across with a long rope of hide, and these men remained at certain distances with the rope over their shoulders to keep the water from having too great an impression upon it. When over, it was fixed to 6 bullocks, and the cart then tossed into the river from the opposite side, when it unavoidably disappeared, and on arriving at the other bank it was generally found to have upset under water; when it was no easy task to set it once more upon its wheels. One cart, in particular, occupied most of a day. Seven days were again consumed in reloading, \&c., during which time $I$ made several excursions among the woods by the river bank; but from the dryness of the season which had clad everything in its autumn or winter garb, very little could be found; I saw some memorable varieties of the Cactus family, of all shapes and sizes. There were two species, or rather perhaps vars., of Passifiora; Mimosas were also very numerous, among which was one allied to the Algaroba, with spines from 4 to 8 inches long; this is called in the country Bonilla or Vanill; its leaves are applied by the natives to cure a dim eyesight. This river flows from the south Andes in a north-east direction towards the Porana, and having traversed a saline tract, becomes so salt that even the cattle refused to drink it. We however obtained good and sweet water only 4 feet from the surface.

[To be continued.] 
Route from Lima by the Quebrada of San Mateo. 105

\begin{tabular}{|c|c|c|}
\hline 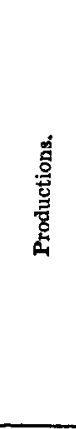 & 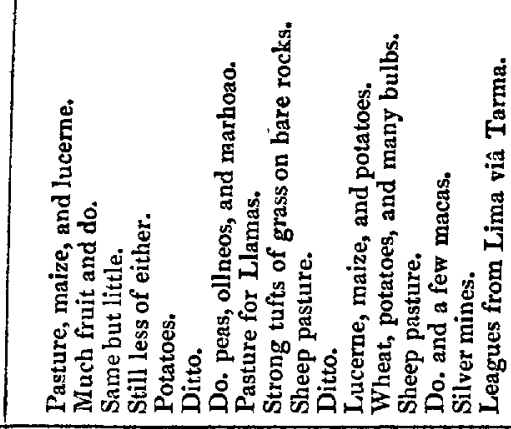 & 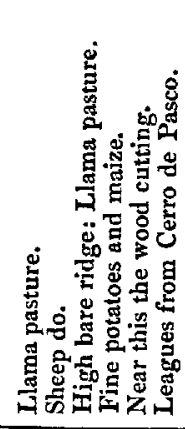 \\
\hline \multirow{2}{*}{ 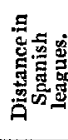 } & 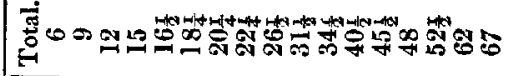 & 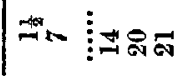 \\
\hline & 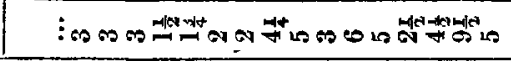 & 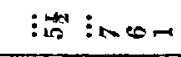 \\
\hline 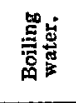 & 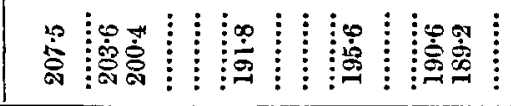 & \begin{tabular}{lll}
$\vdots$ & $\vdots$ \\
\hdashline & $\vdots$ & $\vdots$ \\
$\vdots$ & $\vdots$ & $\vdots$ \\
$\vdots$ & $\vdots$ & $\vdots$
\end{tabular} \\
\hline 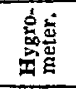 & 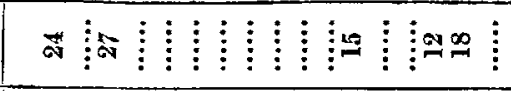 & $\begin{array}{lll} & \vdots \\
\vdots & \vdots & \vdots \\
\end{array}$ \\
\hline 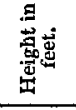 & 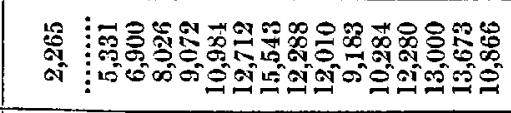 & 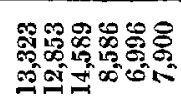 \\
\hline \multirow{2}{*}{ 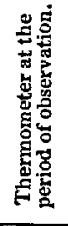 } & 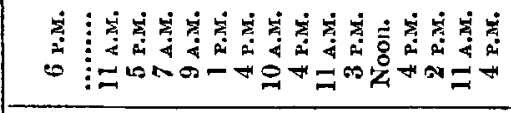 & 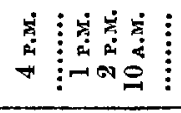 \\
\hline & 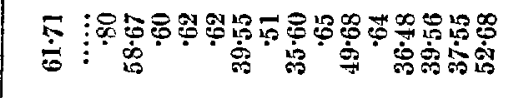 & 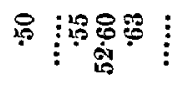 \\
\hline 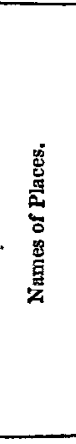 & 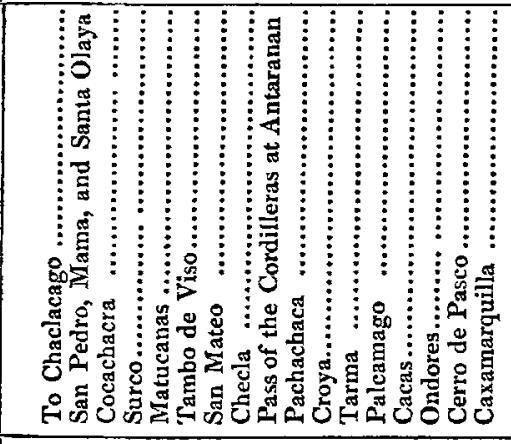 & 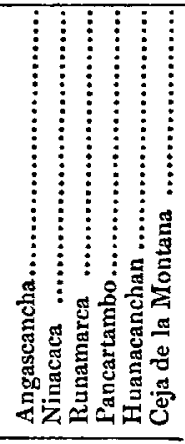 \\
\hline 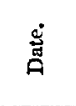 & 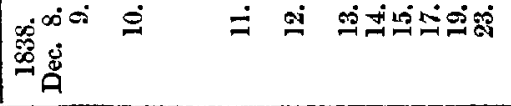 & 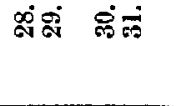 \\
\hline
\end{tabular}

